\title{
EFFECT OF CORROSION INHIBITOR ON PROPERTIES OF CONCRETE AND MORTAR MADE WITH DIFFERENT ADMIXTURES
}

\author{
Ratul Das ${ }^{1}$, Rama Debbarma ${ }^{2}$ \\ ${ }^{1,2}$ Associate Professor, Department of Civil Engineering, National Institute of Technology Agartala, Tripura, India \\ ratulnitagartala@gmail.com,ramadebbarma@gmail.com
}

\begin{abstract}
The effect of corrosion inhibiting admixture on concrete and mortar properties is investigated experimentally. Two reference concretes and mortars are considered, based on ordinary Portland cement (OPC) and slag cement. The effect of corrosion inhibiting admixture (a sodium nitrite-based inhibitor) is evaluated. The properties of the fresh concrete (setting time, density and workability) and of the hardened concrete (compressive strength, bending tensile strength and splitting tensile strength) are evaluated. From experimental results, it has been observed that addition of sodium nitrite as corrosion inhibitor (CI) decreases the compressive strength of OPC mortar at all ages i.e. 7 and 28 days, while an increasing trend is observed for addition of CI in slag cement mortars. There is no remarkable change in density observed for addition of CI for both types of mortars made with OPC and slag cement. 7 days compressive strength decreases with addition of CI to concrete cube made with OPC, while an increasing trend is observed for concrete made with slag cement. 28 days compressive strength of concrete cubes made with both type of cements decreases with addition of CI. Further addition of silica fume (10\%) with combination of CI improves the compressive strength.
\end{abstract}

Index Terms: corrosion inhibitor, silica fume, ordinary Portland cement, slag cement,

\section{INTRODUCTION}

Corrosion of reinforced concrete was first recognized early in the twentieth century and it has worsened in recent years with the wide spread use of sky scraper buildings. Corrosion of reinforcing steel in concrete is not only a very costly problem, but it also endangers structural safety. Corrosion inhibitors are chemicals that may be added to the concrete mix to prevent corrosion of embedded steel. It is essential for practical applicability that the inhibitor should have certain requirements. It should be compatible with other admixtures that are used in concrete. The physical properties and durability of concrete should not be adversely affected. The use of corrosion inhibitors is still in its infancy state. But the use of corrosion inhibiting admixtures has been considered as one of the most cost effective solution to the widespread corrosion problem, due to their convenient and economical application to both new and existing structures.

\section{EXPERIMENTAL SCHEME:}

\subsection{Materials and mix proportions}

Cement-Two types of cement were used in the present study 53 grade OPC (as per IS: 12269) and slag cement (as per IS: 455-1989). Fine aggregate (Sand) - Standard sand: Standard sand of grade I, II, and III in accordance with IS: 650-1966 was used for preparation of mortar samples in the study. Natural sand: Natural sand of grade II as per IS: 383- 1970 was used for preparation of concrete samples. Coarse aggregates: $16 \mathrm{~mm}$ graded crushed stones were used meeting the Indian Standard IS: 383-1970. Silica fume: Silica fume is a byproduct of metallic silicon or silicon alloys. Since, it consists of amorphous silica with a very high surface area (20$30 \mathrm{~m}^{2} / \mathrm{gm}$ ), it shows highly pozzolanic characteristics. This contains $85-95 \% \mathrm{SiO}_{2}$ in non-crystallized state in form of extremely fine particles, which serves as excellent pozzolanic material for use as a Portland cement supplement, Silica fume tends to make the concrete mix more cohesive. In the hardened state, silica fume imparts greater compressive strength. The typical chemical compositions of silica fume are as $\mathrm{SiO}_{2}(85-95 \%), \mathrm{CaO}_{(0.2-0.4 \%)}, \mathrm{Al}_{2} \mathrm{O}_{3}(0.7-15 \%)$, $\mathrm{Fe}_{2} \mathrm{O}_{3}(1-3 \%),{ }^{\mathrm{MgO}}(0.2-0.96 \%)$, Alkalis(0.5-2\%), $\mathrm{SO}_{3}(0.2-0.4 \%)$. In the present study CICO Micro-silica supplied by the structural water Proofing Co., Kolkata has been used.

Super plasticizer-In the present study, Conplast SP 40 manufactured by M/s. Fosroc India Ltd., Bangalore, has been used.

Polymer- In the present study, Sika latex manufactured by Sika Qualcrete Ltd., Calcutta, is used. Sodium Nitrite-Sodium Nitrite $\left(\mathrm{NaNO}_{2}\right)$ is used as corrosion inhibitor in the present study. 


\subsection{Sample Preparation}

Concrete samples- The quantities of ingredients used for $1 \mathrm{~m}^{3}$ of concrete are as follows:

Cement $450 \mathrm{~kg}$, natural sand $680 \mathrm{~kg}, 16 \mathrm{~mm}$ graded coarse aggregate $1100 \mathrm{~kg}$, water/binder is 0.32 , where the binder includes cement as well as silica fume. Super plasticizer (confirming to ASTM C 494 Type F) was used to get the desired workability in terms of slump in the range of $150 \mathrm{~mm}$ to $200 \mathrm{~mm}$. The concrete cube specimens of size $150 \mathrm{~mm}$, while the dimensions for concrete cylinders and prisms are $100 \mathrm{~mm} \times 200 \mathrm{~mm}$ height and $100 \mathrm{~mm} \times 100 \mathrm{~mm} \times 500 \mathrm{~mm}$ respectively. The dosage of sodium nitrite and polymer is kept constant as $5 \%$ and silica fume as $10 \%$ to facilitate direct comparison with the reference samples without sodium nitrite and or polymer.

\subsection{Test methods}

The fresh mixtures of concrete were tested for slump immediately after mixing in a mixer machine, setting time of two types of cement along with various combinations of different admixtures also tested as per Indian standard code of practice. The hardened concretes were tested for 7 days and 28 days compressive strength as per IS 516-1959, 28 days flexural strength as per IS 516-1959 as 28 days split tensile strength as per IS 5816-1970. The compressive strength of mortars were tested at 7 days and 28 days ages. To study the performance in $\mathrm{NaCl}$ solution, one set of mortar and concrete samples were exposed in $5 \% \mathrm{NaCl}$ solution for 28 days while another set of samples were continuously immersed in water for comparison as reference set of samples.

\subsection{TEST RESULTS AND DISCUSSION}

\section{Setting Time}

The results of the initial and final setting time of mortars made with OPC with and without different admixtures are shown in Fig.1 (a) \& 1(b). It has been found that the addition of sodium nitrite as corrosion inhivitor (CI) delayed both initial and final time. For samples made with ordinary Portland cement the delay for initial setting time is more than 200 minutes. Also it is experimented that for samples made with slag cement the delay about 120 minutes. Addition of silica fume reduced the initial setting time appreciably for both types of cement. Similar trend is observed for final setting time for samples made with both types of cement except at $5 \%$ silica fume content, where some contradictory natures are observed though the reason is not clear Fig.2 (a \& b).

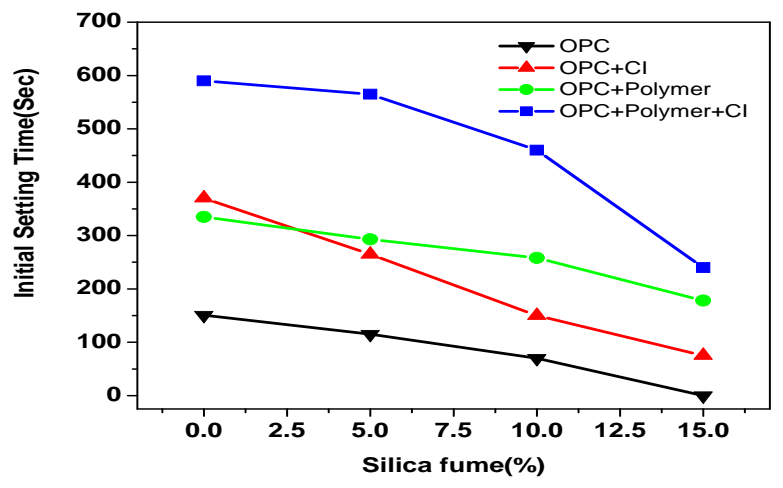

Fig.1(a) Variation of initial setting time due to addition of CI and polymer (OPC)

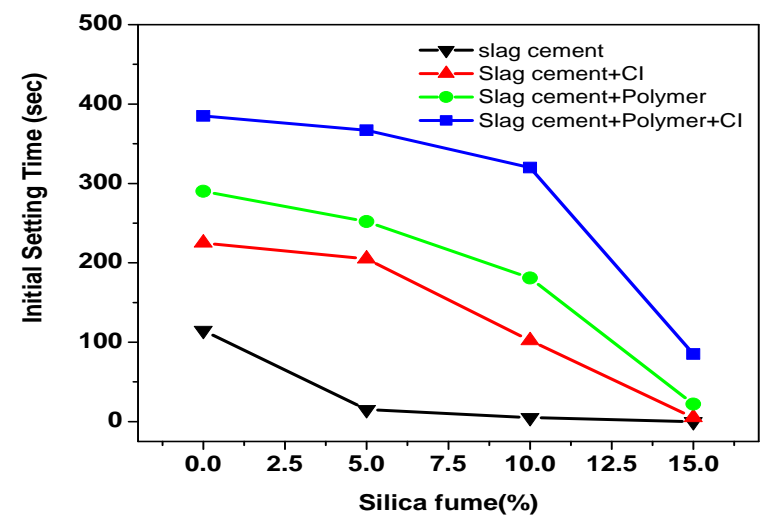

Fig.1(b) Variation of initial setting time due to addition of CI and polymer (Slag cement)

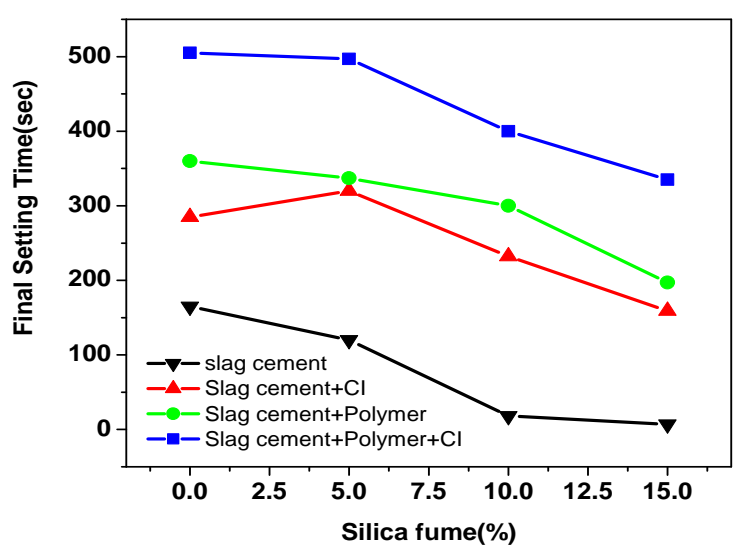

Fig.2(a): Variation of final setting time due to addition of CI and polymer (OPC) 


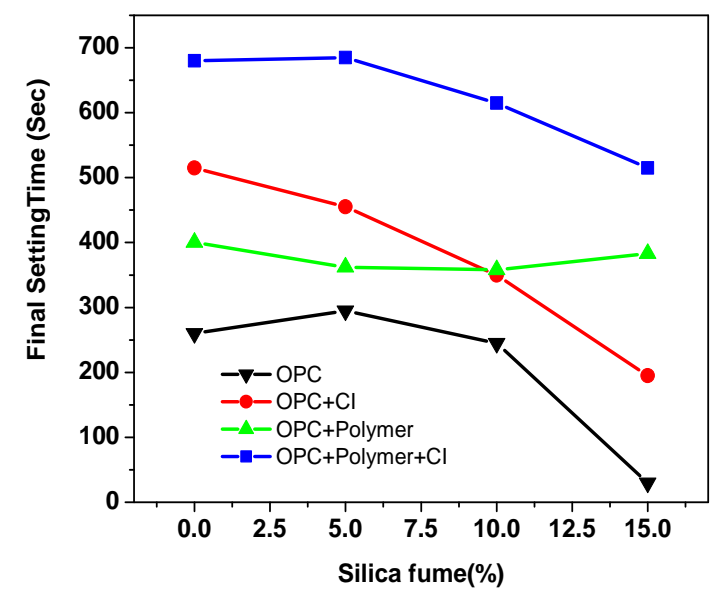

Fig.2(b): Variation of final setting time due to addition of CI and polymer (Slag cement)

\subsection{Compressive strength of concrete/mortar}

For polymer modified mortar, the compressive strength increases for OPC mortars due to incorporation of silica fume as shown in Fig.3 (a). Further reduction in compressive strength is observed for OPC mortars due to addition of CI. It is seen that improvement in compressive strength is noticed for slag cement mortars containing CI in Fig.3 (b). The difference in trends of variation in compressive strength for both OPC mortars and slag cement mortars due to addition of CI with and without polymer are clearly shown in both Figs.

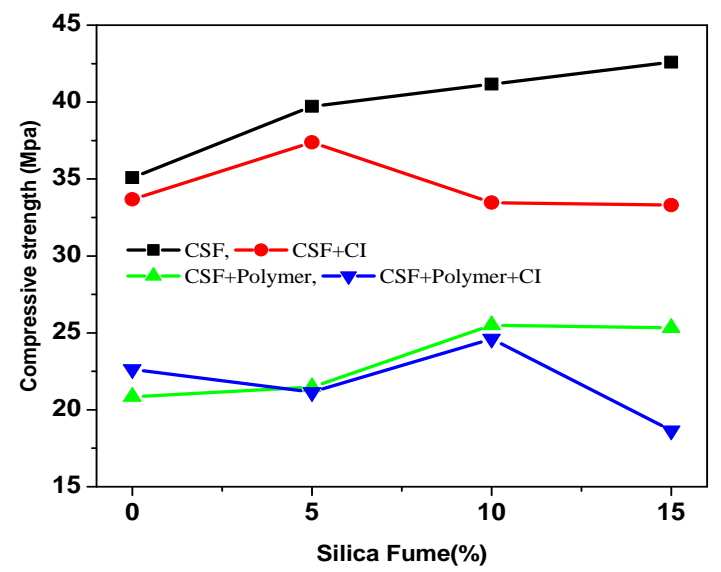

Fig. 3(a): Variation of 28 days compressive strength of OPC mortar with silica fume content

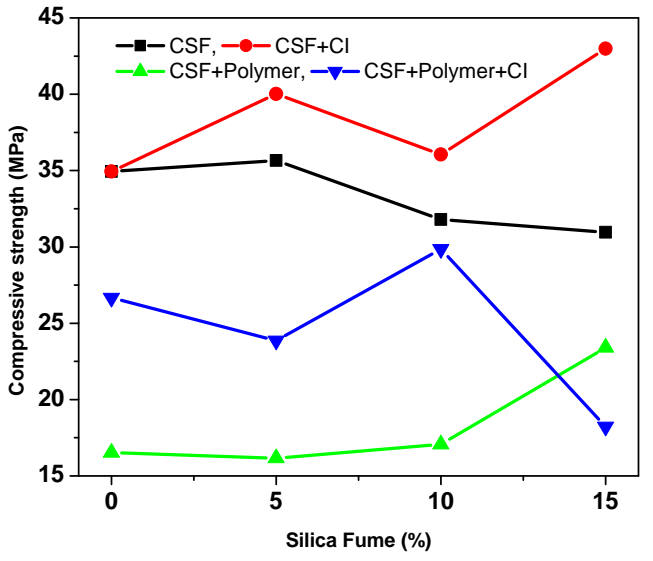

Fig. 3(b): Variation of 28 days compressive strength of slag cement mortar with silica fume content

Fig. 4 represents the variation of 28 days compressive strength of concrete cubes made with OPC and slag cement. For concrete with OPC, 28 days compressive strength decreases with the addition of CI with or without silica fume. For concrete made with slag cement the compressive strength decreases with the addition of CI, but addition of $10 \%$ silica fume with combination of $\mathrm{CI}$ improves the 28 days compressive strength than that of slag cement and sample containing only CI. 7 days compressive strength decreases with addition of CI to concrete cube made with OPC, while an increasing trend is observed for concrete made with slag cement (results are not given here).

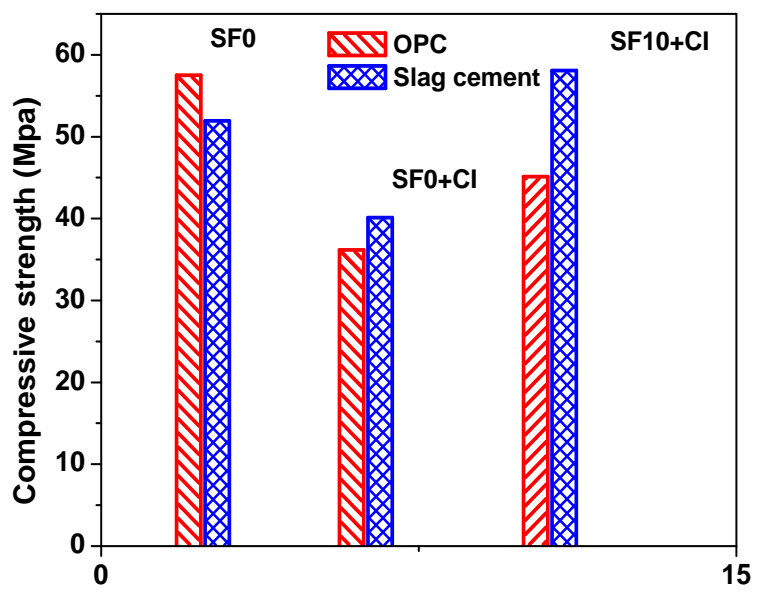

Fig.4: Variation of 28 days compressive strength of concrete made with OPC and Slag cement. 


\subsection{Split Tensile Strength of Concrete}

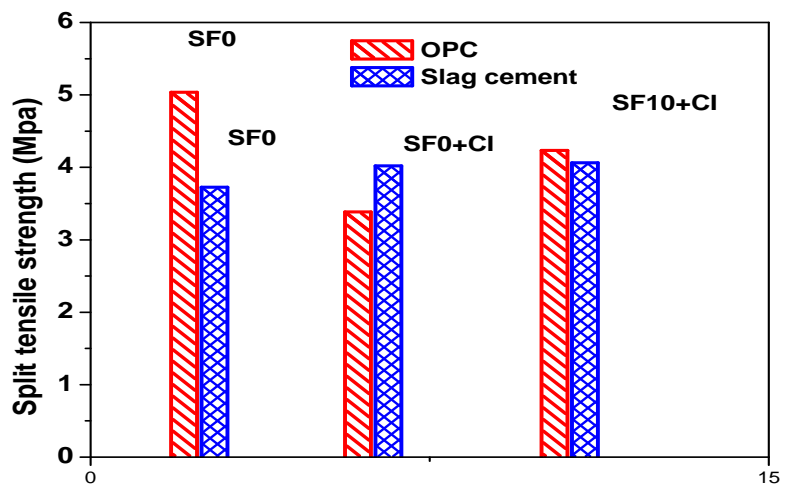

Fig.5: Variation of 28 days Split tensile strength of concrete made with OPC and Slag cement

\subsection{Flexural strength of concrete}

Fig. 6 reflects the variation of 28 days flexural of concrete made with OPC and slag cement due to addition of corrosion inhibitor with and without silica fume. Addition of CI increase the flexural strength of OPC samples and decreases the flexural strength of sample made with slag cement. Further addition of silica fume (10\%) along with the CI causes increases in flexural strength for samples with OPC, while no change is observed for samples made with slag cement.

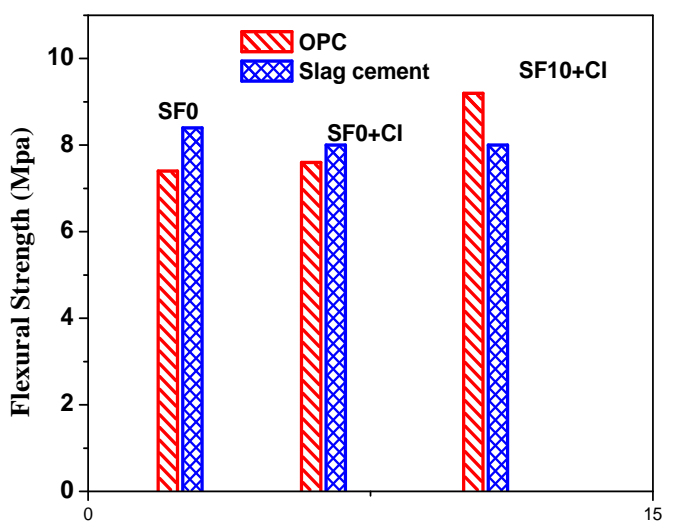

Fig.6: Variation of 28 days Split tensile strength of concrete made with OPC and Slag cement.

\subsection{Effect of Exposure in Chloride Solution}

Concrete samples- Compressive strength and flexural strength of concrete samples exposed in $5 \% \mathrm{NaCl}$ solution compared with a set of water cured samples of same categories are given in Table 1. Variation of compressive strength of concrete cubes due to exposure in $\mathrm{NaCl}$ solution and water or both types of cement are given in Table 1. It is revealed that compressive strength is slightly decreased, for samples containing corrosion inhibitor with and without silica fume, due to exposure in $\mathrm{NaCl}$ solution. Surprisingly, an increase in compressive strength is observed due to exposure in $\mathrm{NaCl}$ solution in comparison to water cured samples without any CI and silica fume for both types of cements. The experimental results shown in the table indicate a decreasing trend in flexural strength of concrete prism, made with both OPC and slag cement, due to exposure in Nacl solution in comparison to water cured samples. An increasing trend is observed due to exposure in $\mathrm{NaCl}$ solution in comparison to watet for samples made with OPC while a reverse trend is found for samples made with slag cement.

Table 1: Variation of compressive and flexural strength of concrete cubes due to exposure in $\mathrm{NaCl}$ solution and water both types of cement.

\begin{tabular}{|c|c|c|c|c|}
\hline $\begin{array}{l}\text { Expo- } \\
\text { sures }\end{array}$ & $\begin{array}{l}\text { Types } \\
\text { of } \\
\text { sample } \\
\text { s } \\
\text { added } \\
\text { with \% } \\
\text { of CI }\end{array}$ & $\begin{array}{l}\text { Types } \\
\text { of } \\
\text { samples } \\
\text { added } \\
\text { with \% } \\
\text { of silica } \\
\text { fume }\end{array}$ & $\begin{array}{l}\quad \text { Av. } \\
\text { Comp. } \\
\text { Strengt } \\
\text { h } \\
\text { of } \\
\text { concret } \\
\text { e } \\
(\mathrm{MPa})\end{array}$ & $\begin{array}{l}\quad \text { Av. } \\
\text { Flexural } \\
\text { Strength } \\
\text { of } \\
\text { Conc. } \\
\text { (MPa) }\end{array}$ \\
\hline \multirow{3}{*}{$\begin{array}{l}\mathrm{NaCl} \\
\text { Solu- } \\
\text { tion }\end{array}$} & $\begin{array}{r}53 \\
\text { OPC }\end{array}$ & 0 & 49.0 & 7.49 \\
\hline & 53 & 0 & 40.2 & 8.99 \\
\hline & $\begin{array}{l}\text { OPC } \\
\quad+5 \% \\
\text { CI }\end{array}$ & 10 & 42.5 & 8.09 \\
\hline \multirow[t]{6}{*}{ Water } & $\begin{array}{r}53 \\
\text { OPC }\end{array}$ & 0 & 49.18 & 8.09 \\
\hline & 53 & 0 & 38.24 & 9.19 \\
\hline & $\begin{array}{l}\text { OPC } \\
+5 \% \\
\mathrm{CI}\end{array}$ & 10 & 45.99 & 7.89 \\
\hline & & 0 & 55.26 & 10.19 \\
\hline & & 0 & 45.59 & 8.09 \\
\hline & & 10 & 51.79 & 8.79 \\
\hline \multirow[t]{3}{*}{ Water } & $\begin{array}{l}\text { Slag } \\
\text { cement }\end{array}$ & 0 & 46.63 & 10.60 \\
\hline & \multirow{2}{*}{$\begin{array}{l}\text { Slag } \\
+5 \% \\
\text { CI } \\
\end{array}$} & 0 & $\begin{array}{l}46.7 \\
\end{array}$ & 8.29 \\
\hline & & 10 & 53.02 & 8.99 \\
\hline
\end{tabular}

\section{CONCLUSIONS}

The following conclusions have been made from experimental results:

- Addition of sodium nitrite (5\% of cement) as CI delays initial and final setting time for both type of samples made with OPC and slag cement. Addition of silica fume reduced the initial setting time appreciably for both types 
of cement. Similar trend is also observed for final setting time except at 5\% silica fume content. Addition of CI into polymer modified concrete causes excessive delay in setting time for both type of cement.

- Addition of sodium nitrite as CI decreases the compressive strength of OPC mortar at 7 and 28 days, while an increasing trend is observed for addition of $\mathrm{CI}$ in slag cement mortars. Similar nature of trend is obtained for addition of CI into polymer modified mortars.

- 28 days compressive strength of concrete cubes made with both type of cements decreases with addition of CI. Further addition of silica fume (10\%) with combination of $\mathrm{CI}$ improves the compressive strength in general.

- Addition of CI decreases the 28 days, split tensile strength for concrete cylinders made with OPC, while an increase in split tensile strength is noticed for concrete made with slag cement. Further addition of silica fume increases the split tensile strength in OPC samples but practically no change is observed for slag cement mortar. 28 days flexural strength increases in concrete prism made with OPC and it decreases in samples of slag cement due to addition of CI.

\section{REFERENCES:}

[1] Craig, R.J. and Wood, L.E.(1970), “ Effective ness of corrosion inhibitors and their influence on the physical properties of Portland cement mortars", Highway Res. Rec, Washington, 328, 77-88.

[2] Gjorv, O.E. (1995), "Effect of condensed silica fume on steel corrosion in concrete", ACI Materials Journal, 92(6), 591-598.

[3] 'Condensed silica fume in concrete', State-of-the -art report, FIP, Thomas Telford, London, 1988, 565-578.

[4] Gautefall, O. and vennesland, O. (1983), "Effects of cracks on the corrosion of embedded steel in silicaconcrete compared to ordinary concrete", Nordic concrete research, 2, 17-28.

[5] Ohama,Y. and Ramachandran, V.S. (1996), “ Polymer modified mortars and concrete", Concrete Admixtures Handbook, $2^{\text {nd }}$ Edition, 558-656.

[6] Malhotra, V.M., Ramachandran, V.S., Feldman, R.F., and Aitein, P.C. (1987), "Condensed silica fume in concrete"' 221, CRC press.

[7] Bayasi, Z and Zhou, Z. (1993), "Properties of silica fume concrete and mortar" ACI Materials Journal, 90(4), 349-356.

[8] Yogendran, V., Langan, B.W., Haque, M.N., and Ward, M.A( 1987), "Silica fume in high strength concrete", ACI Materials Journal, 84(2), 124-149.

\section{BIOGRAPHIES:}

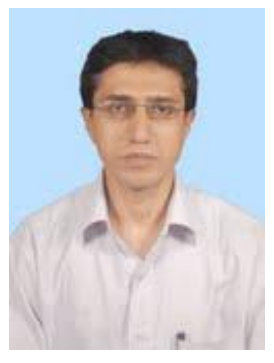

Ratul Das is Associate Professor in Civil Engineering Department at National Institute of Technology Agartala and obtained Ph.D from IIT Kharagpur, INDIA . His area of specialization is Fluvial Hydraulics. He has published more than 10 research papers in various reputed International and National Journals and Conferences.

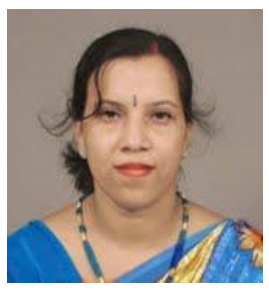

Rama Debbarma is Associate Professor in Civil Engineering Department at National Institute of Technology Agartala and obtained Ph.D from Bengal Engineering \& Science university, Shibpur, INDIA. Her area of specialization is Structural Engineering. She has published more than 10 research papers in various reputed International and National Journals and Conferences. 